\title{
Cinderella and Her True Self: Narrative as a Lost Shoe of Religious Education Tomáš Cyril Havel
}

\begin{abstract}
:
The article offers an insight into an unusual discourse in the Czech environment. It reflects upon the complementarity of religion and fairy tale. It points to the presence of fairy-tale motives in biblical texts and religious motives in fairy tales. Both are illustrated in the context of Christianity by a commentary on the fairy tale Cinderella by the Brothers Grimm. With regard to religious pedagogical discourse, it then invites a narrative turn in religious education, names specific consequences for practice, and points to the possibility of developing a relationship between religious education and fairy tales.
\end{abstract}

Keywords: Religious education, fairy tales, Cinderella, identity, existential frustration, narrative education

Education can hardly be imagined without fairy tales. ${ }^{1}$ They are, in a sense, original forms used for passing the wisdom of one generation to the other. At the same time, they are ideal didactic tools that share models of exemplary behaviour through a figurative story, ${ }^{2}$ for example, distrusting strangers (Little Red Riding Hood) or not opening doors to strangers (The Wolf and the Seven Young Goats).

But fairy tales are not just stories for children. ${ }^{3}$ They also have something to say to teenagers and adults. It is important to understand their speech and read or narrate them through the lens of 'second naivete.'

I look at the phenomenon of fairy tales and the place of narration in education as a teacher of religion. ${ }^{5}$ Thus, I think about it from the point of view of a field ${ }^{6}$ which combines knowledge of

1 Traditional fairy tales co-create our culture. Issues related to their existence are addressed in a number of disciplines such as literary studies, ethnography, psychology, but also pedagogy and theology.

2 Kathrin PÖGE-ALDER, Märchenforschung. Theorien, Methoden, Interpretationen, $3^{\text {rd }}$ ed., Tübingen: Narr Francke Attempto, 2016.

3 In a sense, it is desirable (and it is this way, in an ideal case) if there is a transition between the first and the second naivete (in a sense of the ideas by Paul Ricoeur, or by Hubertus Halbfas who followed Ricoeur, and by others).

4 Through the 'second naivete' (Paul Ricoeur speaks of it as the 'second Copernican turn') one is to experience the world again as a whole reality. Ursula I. MEYER, Paul Ricouer. Die Grundzüge seiner Philosophie, Aachen: Ein-Fach Verlag, 1991, p. 111.

5 Kathrin Pöge-Alder talks about a number of disciplines that deal with understanding fairy tales. In addition to literary science, ethnographic studies or psychology, she also presents theology and pedagogy. See more in PÖGE-ALDER, Märchenforschung...

6 Religious pedagogy is a discipline between pedagogy and theology. Its goals, contents, methods, and institutions of religious education and training are justified pedagogically. However, theology is a meta-pedagogical science for religious pedagogy as this type of pedagogy derives its basic principles from it. In addition to other humanities and social sciences, theology is also a related science for religious pedagogy. Religious pedagogy has a critical dialogue with these sciences and adds new perspectives and impulses. It is a field which 
social sciences and theological disciplines and asks about man in the process of learning (taking into account, for example, the potential of the Christian faith tradition, the experience of the history of Christianity, or great stories of the man-God encounter, for example, in biblical texts). ${ }^{7}$ The issue of the interconnection of biblical texts and traditional fairy tales is not unusual. It is named by researchers such as Dietz-Rüdiger Moser, ${ }^{8}$ Katalin Horn, ${ }^{9}$ Otto Betz, ${ }^{10}$ and Heinrich Dickerhoff. ${ }^{11}$ Similarly, the issue of narrative in (religious) education is not new. ${ }^{12}$

This paper deals with some basic forms of complementarity between religion and fairy tale (1). It gives an example of this complementarity in the context of Christianity using an analysis of Cinderella (2) and summarises the arguments for rediscovering the importance of narrative in religious education (3). The interdisciplinarity of the paper seeks to stimulate further discussion about the consequences of narrative in the broadest sense for the specific practice of religious education. Therefore, its intention is also (for the needs of this discussion) to evaluate available foreign and domestic literature analytically, and thus to bring the topic, which could be seen as some kind of 'Cinderella' in terms of the number of professional texts, into the Czech environment. At the same time, however, narration is an integral part of religious education and can hardly be imagined without it.

\section{Religion and the Fairy Tale}

To juxtapose the concepts of religion and fairy tale is, in a certain sense (and in certain circles) misleading and provocative. 'Fairy tales are for children and so is religion' is one type of reaction. 'Religion is not a fairy tale. This counts for the biblical text even more. It is inadmissible to place these two terms next to each other.' This is the reaction from the other side. A number of renowned authors ${ }^{13}$ in this field point out that this conclusion is too general and superficial.

Herman Gunkel (1862-1932), a pioneer of criticism of literary genres in biblical exegesis, dates the fairy tale as a literary form to an even older period than myths. According to him, it could 'mediate specific motives and texts' even more originally. ${ }^{14} \mathrm{He}$ subsequently considers Jacob's struggle to be such a case (Genesis 32:23-32). ${ }^{15}$ Other biblical texts close to the literary form of the fairy tale ${ }^{16}$ include the Birth of Moses (Exodus 1:1-2:10), the vocation of Samuel (1 Samuel 16:4-13), David and Goliath (1 Samuel 17:1-58), the Birth of Jesus (Luke 2:1-19), the first miraculous catch of fish (Luke 5:1-11), Jesus Heals a Man Born Blind (John 9:1-41), Jesus Feeds the Multitudes

today is no longer defined only by confessional grounding in a particular Church but is devoted to religious education, interfaith dialogue, respect, human dignity...or more broadly also to spiritual manifestations of man and his sensitisation in the broadest sense. Reinhold BOSCHKI, Einführung in die Religionspädagogik, $3^{\text {rd }}$ ed., Darmstadt: WBG, 2015.

8 Dietz-Rüdiger MOSER, Christliche Märchen. Zur Geschichte, Sinngebung und Funktion einiger „Kinder- und Hausmärchen“ der Brüder Grimm, in: Gott im Märchen, ed. Jürgen JANNIG, Kassel: Röth, 1982, pp. 92-113; Dietz-Rüdiger MOSER, Märchen als Paraphrasen biblischer Geschichten. Anmerkungen zu einigen Kinder- und Hausmärchen der Brüder Grimm, Märchenspiegel 1/2004, pp. 3-8.

9 Katalin HORN, Gemeinsame Themen und Motive in der Bibel und in den Märchen, in: Bibel und Märchen, ed. Marie Anna BALMERAEBI, Winterthur: SMG, 2002, pp. 9-19.

10 Otto BETZ, Der abwesend-anwesende Gott in den Volksmärchen, in: Gott im Märchen, ed. Jürgen JANNIG, Kassel: Röth, 1982, pp. 9-24.

11 Heinrich DICKERHOFF, Christentum und Zaubermärchen, Märchenspiegel 3/1999, p. 90; Heinrich DICKERHOFF, Seelenverwandtschaft: Wie Märchen und Religion sich wechselseitig erschließen, Märchenspiegel 1/2004, pp. 20-23.

12 Thorsten KNAUTH, Erzählen im Klassenzimmer. Wenn SchülerInnen aus dem Leben berichten, in: Religionsunterricht aus Schülerperspektive, eds. Thorsten KNAUTH, Sibylla LEUTNER-RAMME and Wolfram WEISSE, Münster: Waxmann, 2000, pp. 95-116; Wolfgang KRAUS, Das erzählte Selbst. Die narrative Konstruktion von Identität in der Spätmoderne, Herbolzheim: Centaurus, 2000.

13 Dietz-Rüdiger MOSER, Katalin HORN, Otto BETZ, Heinrich DICKERHOFF and others.

14 PÖGE-ALDER, Märchenforschung..., p. 268. In Czech, the issue of interpretation of texts is addressed in, for example, Petr POKORNÝ, Hermeneutika jako teorie porozumění. Od základních otázek jazyka k výkladu bible, Praha: Vyšehrad, 2005.

15 Hermann GUNKEL, Das Märchen im Alten Testament, original edition 1917, Frankfurt am Main: Athenäum, 1987, p. 66.

16 If one sees it strictly, the examples given (as far as the literary kind is concerned) are rather legends which use the literary form of fairy tale language to approach a historical event. 
(John 6:1-15), and Jesus Raises a Dead Girl and Heals a Sick Woman (Luke 8:40-56). In the Bible, we encounter the fairy tale as a literary form more often than we might expect. This does not mean that biblical texts 'are a fairy tale'. While fairy tales, of course, speak about miracles, miracles in Bible texts point to God's power, as Horn writes. ${ }^{17}$ Fairy tales are condensed experiences of past generations; biblical stories are challenges of the future with an eschatological dimension. ${ }^{18}$

In addition to differences, however, fairy tales and biblical texts show a number of similarities. For example, Otto Betz points out that while fairy tales do not give a message about God, they, like biblical texts, convey an understanding of the world with its greatness and 'reliable order. ${ }^{19}$ The common theme of both biblical texts and fairy tales is also their dealing with basic topics such as scarcity, injustice, and disruption. ${ }^{20}$ In fairy tales and biblical texts, man is finally presented as one who needs salvation, redemption. ${ }^{21}$

In many fairy tales we encounter explicit religious motives, such as the fairy tale Mary's Child by the Brothers Grimm or a series of stories from the times 'when the Lord Jesus and Peter walked around the world' (Božena Němcová). The prominent researcher Bruno Bettelheim says

Most fairy tales originated at a time when religion was a very important part of life. Thus, they dealt directly or indirectly with religious themes. The stories from A Thousand and One Nights are full of references to the Islamic religion. Many Western fairy tales have a religious content. Most of them, though, are forgotten today and unknown to a wider circle of people. It is precisely because in many of us religious themes do not evoke meaningful general or personal ideas. ${ }^{22}$

From the point of view of religious pedagogy, the comparison of fairy tale and religion is even more important. Both give a name to borderline life situations and the resulting experiences, and thus effectively contribute to personal maturation. Bettelheim, as an educator and paediatric therapist, writes that 'today and in the past, the most important task in the process of raising a child is to help him find meaning in life. ${ }^{23} \mathrm{He}$ considers the potential of religious tradition to be unforgettable.$^{24}$ Or elsewhere: 'If the narrative corresponds to what the child is experiencing inside himself (which cannot be done by a realistic narrative), then it acquires an emotional quality of "truth" in the eyes of the child.25 Viktor Frankl also thematised the importance of finding a meaning in life due to the experience of 'existential frustration ${ }^{26}$ in borderline situations. Paul Tillich says that existential anxiety is ontological anxiety. As it cannot be eliminated, it must be included in the courage to live, to be. ${ }^{27}$ We could relate to this 'existential frustration' the shortest

17 HORN, Gemeinsame..., pp. 14-15.

18 Cf. Ingo BALDERMANN, Úvod do biblické didaktiky, Jihlava: Mlýn, 2004, p. 84.

19 BETZ, Der abwesend-anwesende Gott..., p. 11.

20 Cf. DICKERHOFF, Christentum..., p. 90; HORN, Gemeinsame..., p. 11.

21 Lutz RÖHRICH, Erlösung, in: Enzyklopädie des Märchens. Handwörterbuch zur historischen und vergleichenden Erzählforschung, Volume 4, Berlin: De Gruyter, 1984, pp. 195-222.

22 Bruno BETTELHEIM, Za tajemstvím pohádek, Praha: Portál, 2017, p. 22.

23 BETTELHEIM, Za tajemstvím..., p. 10.

24 Georg MILZNER and Michael UTSCH, Religiöse und spirituelle Sinnsuche in der Psychotherapie: Georg Milzner und Michael Utsch im Gespräch mit Uwe Britten, Göttingen: Vandenhoeck - Ruprecht, 2019.

25 Bruno BETTELHEIM, Kinder brauchen Märchen, $5^{\text {th }}$ ed., München: DTV Verlag, 1982, p. 276.

26 The term is used, for example, by Viktor Frankl in the sense of not fulfilling the basic human need, that is, not fulfilling the desire to find meaning. Frankl says that if the desire to find meaning is not fulfilled, it leads to frustration, and later to an existential vacuum. One begins to doubt the meaning of one's existence and eventually the meaning of life in general. Viktor Emil FRANKL, Člověk hledá smysl: Úvod do logoterapie, Praha: Psychologické nakladatelství J. Kocourek, 1994. 
definition of religion by the recently deceased Catholic theologian Johann Baptist Metz, ${ }^{28}$ which is: 'Unterbrechung. ${ }^{29}$ The spring months of 2020 only underlined the meaning of the word. ${ }^{30}$ The relevance of the religious pedagogical closeness of the relationship between fairy tales and religion is also justified by the phenomenon of narrative. Through this phenomenon, they are transmitted and translated. Narrative and its contribution to the construction of identity is named (with all philosophical-linguistic precision) by Paul Ricoeur. ${ }^{31}$ Heinz Streib then tries to imply this concept in religious pedagogical speech about identity and education. He introduces his text using the words: 'Religion hides a treasure trove of symbols and stories. Symbols and stories are an important mediator through which religion is able to contribute to the formation of time. ${ }^{32}$ Referring to Johann Baptiste Metz, ${ }^{33}$ Streib writes about the consequences of situations in which people are addressed by religious images and stories. In this way the Church really becomes a 'remembering and narrating community ${ }^{34}$ in which people become 'story subjects. 35 It thus foreshadows one of the concrete consequences of the narrative turn for (religious) education. The specific educational potential of fairy tales and the degree of closeness to religious education will be shown by the example of the analysis of one classical fairy tale.

\section{The Breakthrough of Cinderella's True Self}

One form of themed 'existential frustration' presented by Frankl is adolescence. Paul Tillich adds that the appropriate way to deal with frustration is not to eliminate it but 'to include it in the courage to be. This is the concrete potential of the tale Cinderella for the adolescence of young people. It further contributes to the understanding of the importance of Christianity for human life.

\subsection{The Phenomenon of 'Cinderella' in the Bible and Christianity}

The oldest preserved record of the motif of the chosen individual, which is also prominent in the fairy tale Cinderella, is found in 1 Samuel 16:4-13. The story speaks about the prophet Samuel who offers a sacrifice to God in Bethlehem and invites Jesse and his sons to come with him. ${ }^{36}$ Samuel has to anoint one of the sons according to God's mandates. Eliab, a tall good-looking man, appears before Samuel first, so Samuel himself thinks that this is him. But then he is warned not to look at the appearance. Abinadab comes nearer then, and after him all the seven sons of

28 He lived from 1928 to 2019. He is one of the most important theologians of the period after the Second Vatican Council and is best known for his theological concept of 'compassio' Johann Baptist METZ, Memoria passionis: ein provozierendes Gedächtnis in pluralistischer Gesellschaft, Freiburg - Basel - Wien: Herder, 2006.

29 Literally translated as 'interruption'.

30 A major theme of the coronavirus pandemic was the conscious or unconscious, in each case global, experience of the fragility and vulnerability of mankind. What seemed resilient proved to be fragile, vulnerable, mortal. Of course, we had known about the vulnerability of our body, our health but the virus presented us with a new awareness of permanent threat. A specific existential fear, which we may have forgotten during our life, spoke again. And not only that. Debates about the possibility of meeting, renounced cultural performances, or the ban on Church services, have revealed the fragility and vulnerability of social coexistence as such.

31 Paul RICOEUR, Narrative Identität, in: Heidelberger Jahrbücher, svazek 31, ed. Elmar MITTLER, Berlin - Heidelberg, 1987. Ricoeur's notion of narrative identity names a hermeneutic approach that transcends the religious perspective but includes it.

32 Heinz STREIB, Erzählte Zeit als Ermöglichung von Identität: Paul Ricoeurs Begriff der narrativen Identität und seine Implikationen für die religionspädagogische Rede von Identität und Bildung, in: Religion und die Gestaltung der Zeit, eds. David GEORGI and HansGünter HEIMBROCK, Weinheim: Kok, 1994, pp. 181-201, here p. 181.

33 Johann Baptist METZ, Glaube in Geschichte und Gesellschaft. Studien zu einer praktischen Fundamentaltheologie, Freiburg - Basel Wien: Herder, 2016.

34 Erinnerungs- und Erzählgemeinschaft.

35 Cf. STREIB, Erzählte Zeit..., pp. 181-201.

36 Another motif in the Old Testament is the story of Abraham. Martin BAUSCHKE, Abraham und Aschenputtel: Brückenschlag zwischen Bibel und Märchen, Stuttgart: Radius, 2006; or the story of Cain and Abel, or Jacob and Esau. BETTELHEIM, Kinder..., pp. 275-324. 
Jesse. Then Samuel asks Jesse if they really are all his sons, and he is given the answer that there is another who is grazing sheep. So, Samuel calls him, and when he sees the youngest red-haired boy, he knows that he is the one to be anointed the king of Israel. 'But the LorD said to Samuel, "Do not look on his appearance or on the height of his stature, because I have rejected him. For the LORD sees not as man sees: man looks on the outward appearance, but the LoRD looks on the heart"' (1 Samuel 16:7). ${ }^{37}$

In the New Testament, man is raised from the dust. Man is given the dignity of Mary as God has looked on 'the humble estate of his servant', and she becomes the mother of Jesus (Luke 1:46-55). We literally read in Mary's Song: 'And Mary said, "My soul magnifies the Lord, and my spirit rejoices in God my Savior, for he has looked on the humble estate of his servant. For behold, from now on all generations will call me blessed; for he who is mighty has done great things for me, and holy is his name."

The religiousness of these motives lies in the fact that the one who raises, finds affection, entrusts to the royal throne, and represents the driving force of this event is God. He intervenes from the outside, but through people..$^{38}$

The motif of choosing captured in the fairy tale Cinderella is also repeatedly mentioned, for example, by Martin Luther in his interpretation of Mary's Song from 1521. In the history of Christianity, however, this motif has been shifted due to the work of preachers (for example, Johann Geiler von Kaysersberg, 1445-1510). It helps to better understand the religious dimension of the desire for recognition in the midst of humiliation, for self-affirmation in the midst of an unwilling world, for reward due to hardships. These are all motifs connecting both the tale Cinderella and the abovementioned sermons. There is also an important difference: the sermons move the reason for hope to the 'other' metaphysical world while the fairy tale places the message of the 'other' metaphysical level of reality into the experience of earthly love. ${ }^{39}$

\subsection{Courage to Dream}

'A rich man had a wife. One day she realised that her final hour was approaching and she called her only daughter to her bedside...' This is how the story of Cinderella begins as told by the Brothers Grimm..$^{40}$ The Brothers Grimm are harsher in their narrative ${ }^{41}$ but everyone knows who Cinderella is. Everyone has experienced what it is like 'to feel like Cinderella'.

The German psychoanalyst Eugen Drewermann portrays the character of the fairy tale Cinderella as follows: 'Cinderella is a story about the victory of beauty over shame and true being over false pretence. Cinderella, it is an unfulfilled dream of a hidden kingdom in every human being. The fairy tale Cinderella is told everywhere where people continue to believe in the greater dignity of their being. 42

Cinderella is a character trait or human destiny that we can meet even today. To understand the tale of Cinderella means to understand oneself in a similar situation, to encourage oneself to re-

37 In the Old Testament, on other pages, we can find a kind of continuation of the story of David in other contexts. David becomes a typical embodiment of the whole nation. Israel, a neglected nation of nomads, is exalted to the dignity and glory of the royal people by David on whose side God stands.

Cf. Eugen DREWERMANN, Landschaften der Seele oder: Wie man die Angst überwindet. Grimms Märchen tiefenpsychologisch gedeutet, Volume 3, Ostfildern: Patmos, 2015, p. 122.

39 Cf. DREWERMANN, Landschaften..., p. 123.

40 Wilhelm GRIMM and Jakob GRIMM, Pohádky bratří Grimmů. Kompletní „Malé vydáni“, Praha: Brio, 2004, pp. 190-202.

41 Harsher than Božena NĚMCOVÁ, O Popelce a jiné pohádky, Praha: Nava, 1994.

42 Cf. DREWERMANN, Landschaften..., pp. 118-119. 
main in one's most secret dreams and desires, and to trust in the value of one's existence. It means to believe in your 'fairy-tale' dreams despite the painful 'reality'.

\subsection{Cinderella Is Not the 'American Dream'}

Cinderella's feelings take the form of an underestimation of her talents and abilities in an environment which she does not want or accept. If we looked for the opposite, it would be the 'American dream' which states that one can be anything if one wants to and believes in oneself. ${ }^{43}$ One can become a millionaire even if starting out as a shoe shiner, a simple boy can become a president, a young man barely skating on a country pond can become a professional ice hockey star. He just has to want it, and purposefully work on his career. The 'American Dream' is compatible with big shoulders and strong elbows. It promises that if one goes after one's own dreams, one will make them come true. 'Cinderella', on the other hand, has the character of inconspicuousness, neglect, underestimation. In order to grow up, she is waiting to be addressed and fought for by someone. In popular terms: sit down, girl, in the corner, if you are kind, they will find you (Czech proverb). The fairy tale Cinderella does not tell about the rise to power, wealth, and fame - that is, self-realisation achieved by self-confident action and performance. Cinderella depicts a breakthrough of the true self with all the beauty and greatness that comes only after a self-affirming discovery made by another person, that is, as a result of a unique relationship. Its theme is choosing, rather than narcissistic self-assertion. Cinderella doesn't need to do much but it certainly doesn't mean that she can fold her hands in the lap.

The courage to be oneself is not a matter of course. There are several kinds of fear presented by Fritz Riemann: the fear of surrendering oneself, the fear of self-realisation, the fear of transience, and the fear of irreversibility. These four forms of fear put man in the role of 'Cinderella' and prevent him from growing into the integrity of his existence. ${ }^{44}$ Riemann also writes about what helps people not to avoid contact with others due to their schizoid fear for themselves, not to remain depressive in a relationship of addiction, not to compulsively cling to common things due to the fear of change and transience, not to hysterically succumb to arbitrariness. One should also avoid fear of necessity. ${ }^{45}$

The fairy tale suggests a solution and hides at least three keys to action:

- Although Cinderella by the Brothers Grimm is passive at first glance, her passivity is only apparent. Cinderella mobilises her inner strength all the time thanks to the favour of everyday little things. She doesn't ask for a gift but accepts any small thing someone comes across. She also finds small and inconspicuous friends in the pigeons. At the same time, she continues to long for the same conditions as her 'sisters' have. She longs to go to the ball, to be beautiful, to meet the prince...

- Then the favour of good forces enters Cinderella's life. A woman from another world, a fairy or, in some versions, a dead mother who likes her, advises and encourages her. This is a description of a situation of repeated reassurance by another person. Such a situation can be created using suitable conditions. When we think of the 'fairy-tale aspect' of this revelation which, in the Jewish-Christian religious tradition, takes the form

43 Max WEBER speaks in a similar sense of Protestant ethics as of a religiously motivated attitude to work and vocation within Protestantism. Max WEBER, Protestantische Ethik und der Geist des Kapitalismus, Köln: Anaconda Verlag, 2018.

44 Fritz RIEMANN, Grundformen der Angst, $41^{\text {st }}$ ed., München: Ernst Reinhardt, 2013.

45 Kriteria viz RIEMANN, Grundformen..., p. 17. 
of God's 'choosing', we find a cure that unites many small supporting elements and forms them into courage. Cinderella begins to act on her own, not as she is expected or forced to by circumstances.

- The transformation does not come immediately - Cinderella's true self initially breaks through only within a limited time. The spell is valid until midnight only, then one needs to sit in the ashes again. After some time, when the prince puts on her slipper (which is so unique that it only fits her), Cinderella definitively changes. By declaring her property, she turns magical moments into real life.

The example of the religious pedagogical reflection upon this classic fairy tale shows a parallel to the biblical motive of choosing and also describes a specific path of spiritual growth. It is the right to efficient use of internal resources, the need to meet with personal support from others, and the need of time for the process.

\section{3. (Religious) Education - Narrative Education}

Following the example of the analysis of the educational potential of the classic fairy tale within its closeness to religious education, in this part I will try to expand the question of the relationship between fairy tale and religion in a more general direction towards the topic of narrative in (religious) educational processes. ${ }^{46}$

Reading fairy tales or, even better, listening to the narrative in general is a phenomenon that invites readers or listeners to confrontation - in the protected environment of the story - with borderline situations. Thanks to fairy tales, they learn through these - often unhappy - experiences to talk about them while using story images or comparing situations or the nature of the acting characters. Through a narrative dialogue with the story, we can learn both to act more responsibly and to appreciate the time spent with the story as unique, rare, and, in a sense, 'sacred. ${ }^{47}$ The images of the story, the comparison to situations, or the character of the characters also inadvertently provide a vocabulary for religious speech and thus help to pronounce the unspeakable. ${ }^{48}$

If we want to capture the potential of storytelling for religious education, generally deepened, for example, also in narrative theology, ${ }^{49}$ it is necessary to focus on the question of identity and the question of the religious pedagogical conception of education, especially with regard to the discourse of the mentioned type of theology. ${ }^{50}$ According to Heinz Streib, even this whole effort can be narrowed down to a critical assessment of the tension between the child's knowledge and psychosocial development. This can take the form of knowledge or, conversely, psychosocial one-sidedness which in turn projects into a person's identity and into the focus of religious education as such. ${ }^{51}$

46 Ludmila Muchová deals in detail with narrative as a didactic form of religious education. Ludmila MUCHOVÁ, Cíle a cesty k hlubšimu lidství. Didaktika výuky náboženství pro 21. století, České Budějovice: Petrinum, 2017, pp. 112-118.

47 Cf. STREIB, Erzählte Zeit..., p. 182.

48 Ludmila Muchová pays more attention to the issue of understanding the religious form of speech. Ludmila MUCHOVÁ, Rámcové a školní vzdělávací programy a náboženská výchova. Texty na pomoc studentům oboru Učitelství náboženství a etiky, nevydaný rukopis, pp. 29-90.

49 Christoph WIESINGER and Stephan AHRNKE (eds.), Erzählen: Ingrid Schoberth zum 60. Geburtstag, Göttingen: Vandenhoeck Ruprecht, 2019; Xavier LAKSHMANN, Textual linguistic theology in Paul Ricoeur, Bern - Frankfurt - Berlin - Vienna: Peter Lang, 2016.

50 Reinhold Boschki, for example, writes in detail about this issue when he discusses the origin of religious pedagogy as a scientific field and names the core of the problem in connection with different concepts of theological anthropology. See more BOSCHKI, Einführung..., pp. 37-48.

51 Cf. STREIB, Erzählte Zeit..., p. 189. 
Religious pedagogy - precisely due to its interdisciplinary nature ${ }^{52}$ - makes it possible to capitalise on the potential of a joint search of, for example, biblical theology and psychology. This is evident from the example of the thematic fairy tale Cinderella but also from a number of other examples. ${ }^{53}$ The unifying element is the search for the imaginary 'red thread of life' which is accompanied by questions such as: What is it? What characterizes it? Who is involved? What creates it? Then there is the question which is decisive from the religious-pedagogical point of view and carries a more complex question of God in itself: Who writes the story of my life? ?4 $^{54}$

Heinz Streib thus brought the concept of 'narrative identity' formulated by Ricoeur into the practice of religious education and, in this context, began to speak of 'narrative education'.

Its outlines would then be as follows: ${ }^{55}$

\section{- Narrative taking into account working with symbols}

Experiencing symbols and stories is crucial for the formation of (religious) identity. ${ }^{56}$ When we tell the story of our lives, we also interpret it. Continuity and integration are crucial factors in such narration. Biblical texts also tell stories about the search for identity, about conflicts of life roles, etc. For example, the story of how Jesus calmed the storm (Mark 4:35-41) may point to a life stage in which one struggles with storms of relationship change, job insecurity, or even the fear of death ${ }^{57}$ - it may point to processes which are understandable for listeners in analogy with their own life story. In this way, we gain words, images, and motivation to express and narrate our personal, inner story. ${ }^{58}$

For the practice of religious education itself, there is a requirement to work with (biblical) stories but also with the need to offer the opportunity to 'read the text of your own life story', that is, the right to work with a biography..$^{59}$

The benefit of such a narration is the knowledge that even 'my life story' is multi-layered, inexhaustible, and open to the future.

\section{- Narrative taking into account play and the development of creativity}

According to the paradigm of narrative hermeneutics, there is not just one story but several of them. The interpretation of one's own life is imperfect, sketchy, and so is the interpretation of the lives of others. An unambiguous, complete, and generally valid autobiography is, in this sense, impossible. Therefore, we must be able to learn how to deal with imperfections, incompleteness, and how to withstand openness. ${ }^{60}$ The identity created by telling a personal life story resonates in the context of other different life stories. In this way it highlights unity and

52 BOSCHKI, Einführung..., pp. 11-15.

53 For example, Hansel and Gretel, Little Red Riding Hood, Snow White, Sleeping Beauty, The Frog King, The Three Feathers, Three Golden Hairs of Grandpa Know-All, or Iron John (Prince Bayaya). See the works of these authors (Bettelheim, Dickerhoff, Betz, Horn and others).

54 Walter SPARN (ed.), Wer schreibt meine Lebensgeschichte? Biographie, Autobiographie, Hagiographie und ihre Entstehungszusammenhänge, Gütersloh: Gütersloher Verlagshaus, 1990.

55 For more information see STREIB, Erzählte Zeit..., pp. 192-195.

56 Cf., for example, Klaus EBERT, Religion im Alltag. Überlegungen zur These vom Funktionsverlust von Religion, in: Alltagswelt und Ethik. Beiträge zu einem sozial-ethischen Problemfeld, ed. Klaus EBERT, Wuppertal: Hammer, 1988, pp. 17-53.

57 Eva MUROŇOVÁ, Tomáš Cyril HAVEL and Hanni NEUBAUER, Gespräche mit Franz Kett über sein Leben und seine Pädagogik, Gröbenzell: Franz Kett-Verlag GSEB, 2015, pp. 133-134.

58 Cf. Jürgen LOTT, Erfahrung - Religion - Glaube. Probleme, Konzepte und Perspektiven religionspädagogischen Handelns in Schule und Gemeinde, Weinheim: DSV, 1991, p. 224.

59 MUCHOVÁ, Cíle a cesty..., pp. 118-122.

60 Cf. Wilna A. J. MEIJER, The Plural Self. A Hermeneutical View on Identity and Plurality, (Paper presented on the $8^{\text {th }}$ Meeting of the International Seminar on Religious Education and Values, Banff, Alberta), Manuscript, 1992, pp. 5, 9. Cited in accordance with STREIB, Erzählte Zeit..., pp. 181-201. 
represents an invitation towards a creative approach.

For one's own practice of religious education, this may mean the right to develop creative competence. One should creatively develop openness to different interpretations and seek current patterns for understanding one's own life, the lives of others, and the world as such. This applies not only to fairy tales but also to biblical texts in which Baldermann emphasises the potential to become a framework story. ${ }^{61}$ Such a story places a certain problem of a selected biblical text in a situation in which it may appear as a symbolic story. Thus, it can become a 'contextual story'62 which leads a person to his differentiated perception.

The consequence of the realisation of a narrative that takes into account play and the development of creativity is the joy of a creative approach to life and its stories. They may include the story of religion.

\section{- Narrative taking into account the courage to fragmentation}

Education is and will remain an open process, and the same is true of religious education. It is not aimed at achieving a specific state. It is rather a movement and a vision. The concept of (religious) identity evokes the idea of the attainability of a certain harmony, completeness, permanence. Unfortunately, this is accompanied by the temptation to lead education and evaluate its quality through achieving such goals. ${ }^{63}$ However, religious education should retain the form of critical regulation and 'uncertain vibration, ${ }^{64}$ rather than blind normativity. Religious education must be warned of the temptation of ideologisation, and it must acknowledge the unattainability of perfect being, the reality of division, inner rupture, and incompleteness (fragmentation), and to work with these facts thoughtfully. ${ }^{65}$

For one's own practice of religious education, this means the right to accept the fact that the new also includes the extinction and loss of the former. Figuratively speaking, today we are the ruins of our future. We are buildings which might not be finished by anyone. Such education will support an environment of open creativity and will resemble a laboratory looking for new ways. ${ }^{66}$

The narration carried out in this way will contribute to the ability to think, ask questions, think critically, and thus be immunised against the infection of fundamentalism, among other things.

\section{- Narrative taking into account the potential of diversity}

The uniqueness of the story and the courage to tell it, especially when it comes to the story of one's own life, are circumstances that necessarily bring the right to reflect upon the pedagogical approach at the level of teacher-student or student-student. Pupils thus become partners and subjects, not objects of pedagogical work. Everyone, including the teacher, bears their share of responsibility for the atmosphere. In these conditions, they encounter in the diversity of their stories, including the stories of specific religions. This situation includes the requirement for the quality of interaction between people with different perspectives, different socialisation, different interests, and different abilities to reflect upon these processes. ${ }^{67}$

61 Walter NEIDHARDT and Hans EGGENBERGER (eds.), Erzählbuch zur Bibel, volume 1 (1975), volume 2 (1989), Zürch: Lahr.

62 Cf. BALDERMANN, Úvod..., p. 107.

63 The concept of 'pedagogy of discomfort', authored by Megan Boler, is critical of this model of pedagogical thinking. Megan BOLER, Feeling Power: Emotions and Education, New York: Routledge, 1999. But also the other authors, see Daniel BURGHARDT, Nadine DZIABEL and Thomas HÖHNE (eds.), Vulnerabilität. Pädagogische Herausforderungen, Stuttgart: Kohlhammer, 2017; Hildegund KEUL and Thomas MÜLLER (eds.), Verwundbar. Theologische und humanwissenschaftliche Perspektiven zur menschlichen Vulnerabilität, Würzburg: Echter, 2020.

64 Tomáš HALÍK, Co je bez chvění, není pevné. Labyrintem světa s vírou a pochybností, Praha: Lidové noviny, 2002.

65 Cf. Henning LUTHER, Religion und Alltag. Bausteine zu einer Praktischen Theologie des Subjekts, Stuttgart: Radius, 1992, pp. 150-159.

66 Cf. LUTHER, Religion..., p. 170.

67 Cf. MEIJER, The Plural..., p. 6. 
For the practice of religious education, this means the right to educate towards openness. In this way, 'foreign' stories become essential elements of common learning precisely because of their 'foreignness. ${ }^{68}$

The narrative which takes into account the potential of diversity opens up space for appreciating the diversity of relationships, and thus the possibility of understanding the Christian conception of God in an original way.

\subsection{Narrativity in the Practice of Religious Education in the Czech Republic}

Narrative in general ${ }^{69}$ and fairy tales in religious education in particular are, in a sense, 'Cinderella' in the Czech environment. We can, however, still find fairy tales in the methodological materials for preschool education and teaching of religion in primary schools. In the programmes of initiation catechesis, the topic of fairy tales is not included at all and narrativity is offered mainly within the work with biblical stories, or in connection with the biographies of saints.

Didactic ways of working where we can meet narrative in religious education are, for example, bibliodrama and work with biblical characters, ${ }^{70}$ the pedagogy of Franz Kett, ${ }^{71}$ and the catechesis of the Good Shepherd. ${ }^{72}$ Only Franz Kett's pedagogy offers direct work with a fairy tale.

The ability to tell a story and work with it is part of the basic professional equipment of a teacher, especially at lower levels of education. Narrative in general education can be found, for example, in storytelling, creative drama, working with 'stories from a briefcase', or within the development of pre-reading and reading literacy. ${ }^{73}$

If we, for the purposes of this text, deal with the issue of the relationship between narrativity (in the form of work with fairy tales) and religious education only, I see two ways. One is named by Ludmila Muchová. In her proposal for a framework programme of religious education for available hourly allowance, she also presents the area of 'opening and developing basic existential experience and their deepening into elementary religious experience' as a contribution to the formation and development of key competencies. This is then specified in more detail in the thematic unit 'openness to basic life experience. ${ }^{74}$ Fairy tales can be a proven tool here. The second way is the area of 'understanding the religious form of biblical language ${ }^{75}$ which, in a broader sense, presupposes understanding of the archetypal images in classic fairy tales in general.

The proposal of the framework programme of religious education as a cross-sectional theme in the abovementioned script opens the way to work with storytelling even more specifically. ${ }^{76}$ In the field of knowledge, skills, and abilities, it formulates the right to understand the truth about the world through various literary and thought forms. ${ }^{77}$ As part of examples of methodological elaboration, we will also find the story $O$ tajuplném koši (About the Mysterious Basket) and its

68 See more in, for example, Tomáš Cyril HAVEL, Das kann doch nicht wahr sein! Der Verlust der Wahrheit als Herausforderung für Religionspädagogik, in: When East and West Meet. Contemporary Perspectives on Religious Education in Honour of Ludmila Muchová, ed. František ŠTĚCH and Bert ROEBBEN, Svitavy: Trinitas, 2019, pp. 187-198.

69 In the case of religious education, this includes, for example, the testimonies of contemporary believers about their relationship with Christ, or specific gospel parables which are in the form of narration.

70 C České katolické biblické dílo (on-line), available: www.biblickedilo.cz, cited $26^{\text {th }}$ June 2020.

71 () Společnost Pedagogiky Franze Ketta (on-line), available at: www.kett.cz, cited $26^{\text {th }}$ June 2020.

72 (c) Katecheze Dobrého Pastýŕre (on-line), available at: www.katechezedobrehopastyre.cz, cited $26^{\text {th }}$ June 2020.

73 This summary is based on the author's many years of experience with religious education in the Czech environment. However, it does not claim completeness.

74 See more in MUCHOVÁ, Rámcové..., pp. 21f.

75 See more in MUCHOVÁ, Rámcové..., pp. $29 f$.

76 In addition to the legends of St Catherine, St Christopher, The Other Wise Man and others, there are also the following classic fairy tales.

77 MUCHOVÁ, Rámcové..., p. 27. 
connection to the biblical story about a blind beggar called Bartimaeus ${ }^{78}$ or the fairy tale the Star Money which is a combination of fairy tale and legendary form. In this tale, the children 'experience the simply expressed ethos of Jesus: those who give out of the goodness of their hearts will receive a hundred times more. ${ }^{79}$ According to Muchová, another fairy tale suitable for inclusion in religious education can also be the classic fairy tale the Three Feathers by the Brothers Grimm. Its aim is to know how to reveal paradoxical statements and meet the clash of 'superficial and inner experience of the world and appreciate the inner approach to the world'. ${ }^{0}$

The optional subject of religion in primary schools (which is specified in this way) is a part of the document Osnovy k výuce náboženské výchovy ř́mskokatolické církve v 1.-9. ročníku základní školy (Curriculum for Teaching Religious Education of the Roman Catholic Church in the $1^{\text {st }}-9^{\text {th }}$ classes). ${ }^{81}$

The most recent ČBK (Episcopal Conference of Czech Republic) document on the topic of religious education Dokument o směrování katecheze a náboženského vzdělávání v České republice (Document on the Direction of Catechesis and Religious Education in the Czech Republic), ${ }^{82}$ which has a material-kerygmatic focus. ${ }^{83}$

In the methodological materials prepared in connection with the curriculum for teaching religion by Eva Muroňová et al. and published under the heading of the Diocese of Ostrava-Opava for some classes of primary and secondary school, we encounter work with stories and fairy tales and their narration in many places. ${ }^{84}$ Of the classic fairy tales, these are mainly The Little Match Girl by Hans Christian Andersen, or the Star Money of the Brothers Grimm.

Another material for teaching religion, in which we can also find stimuli for working with a figurative story, is the magazine Duha ${ }^{85}$ or methodological materials containing didactic procedures

78 Ibid., pp. 35-38.

79 Ibid., p. 39.

80 Ibid., p. 82 .

81 C ČBK, Osnovy k výuce náboženské výchovy římskokatolické církve v 1.-9. ročníku základní školy. The text was prepared by Ludmila Muchová and Eva Muroňová (on-line), available at: https://cbk.blob.core.windows.net/cms/ContentItems/297_00297/27-osnovy-kvyuce-nv.pdf, cited $26^{\text {th }}$ June 2020.

82 (c) ČBK, Dokument o směřování katecheze a náboženského vzdělávání v České republice (on-line), available at: https://cbk.blob.core. windows.net/cms/ContentItems/297_00297/38-dokument-20o-20smerovani-20katecheze.pdf, cited $26^{\text {th }}$ June 2020.

83 See more in Georg HILGER, Stephan LEIMGRUBER and Hans-Georg ZIEBERTZ, Religionsdidaktik: Ein Leitfaden für Studium, Ausbildung und Beruf, München: Kösel, 2. ed, 2003, pp. 42-66.

84 An example, in the methodology for the $4^{\text {th }}$ class, is Theseus' labyrinth in connection with work with the Bible, p. 11; The Parable of the Fisherman with the theme of the idea of heaven, p. 29; The legend of St Lucia, pp. 35; The Hall of Light in connection with Jesus' statement I am the light of the world, p. 41. (Eva MUROŇOVÁ, S tebou na cestě: Metodika k pracovním listům náboženské výchovy pro 4. třídu, Brno: Kartuziánské nakladatelství, 2004); in the methodology for the $5^{\text {th }}$ class it is work with the literary text The Holy Night by Selma Lagerlöf, p. 49; The Little Prince in connection with the statement I am the vine, p. 66; The Little Match Girl by H. C. Andersen in connection with the Way of the Cross, p. 80. (Eva MUROŇOVÁ, Společně vytváríme boží království: Metodika k pracovním listům náboženské výchovy pro 5. tř́du, Brno: Kartuziánské nakladatelství, 2004); in the methodology for $6^{\text {th }}$ class The Story of the Three Trees in connection with Easter, p. 79 (Eva MUROŇOVÁ, Společně objevujeme víru: Metodika a pracovní listy k výuce náboženské výchovy pro 6. tř́du ZŠ, Brno: Kartuziánské nakladatelství, 2004); in the methodology for $7^{\text {th }}$ class The Star Talers in connection with Christmas, p. 85; A fairy tale Chléb štěstí (The Bread of Happiness) in the theme of the sacraments, p. 117 (Eva MUROŇVÁ, Rosteme ve víre: Metodika a pracovní listy $k$ výuce náboženské výchovy pro 7. tř́du ZŠ, Brno: Kartuziánské nakladatelství, 2006); in the methodology for the $8^{\text {th }}$ class The Little Prince in connection with the topic of prayer, p. 144; The Hundredth Name of God in connection with the first commandment of the Ten Commandments, p. 115 (Eva MUROŇOVÁ and Ludmila MUCHOVÁ, Utvářet život: Metodika a pracovní listy $k$ výuce náboženské výchovy pro 8. trídu Ž̌, Brno: Kartuziánské nakladatelství, 2009).

85 I choose from recent years Čtyři příběhy $\mathrm{k}$ př́pravě na slavení svátosti eucharistie - Four stories in preparation for the celebration of the Sacrament of the Eucharist(15-2012/2013), Kamenná polévka - Stone Soup (13-2012/2013), Nebeská polévka - Heavenly Soup (142012/2013), Slepičí polévka a vůně růží - Chicken Soup and the Scent of Roses (12-2012/2013), Karolína se zeleným nosem - Caroline with the Green Nose (1-2012/2013), Všechny barvy světa - All the Colours of the World (1-2013/2014), Červený král a bílá hvězda - The Red King and the White Star (9-2013/2014), Neboj se, nejsi na to sám - Don't Worry, You're Not Alone (1-2014/2015), Pírka duhového ptáčka - Rainbow Bird Feather (1-2015/2016), Proč musím v neděli do kostela - Why Do I Have to Go to Church on Sunday (18-2016/2017), Vánoce ve chlévě - Christmas in the Barn (8-2019/2020). 
of Franz Kett's pedagogy. ${ }^{86}$

Although it may seem that many examples reflect the richly reflected upon practice in the application of narrative (fairy tales) in religious education, this is not the case. It is obvious that this, in a sense, is kind of 'Cinderella'. It is a concept of religious education based on anthropological and existential starting points which is a marginal issue in the Czech discussion of religious education and catechesis.

\title{
Conclusion
}

Fairy tales, narrativity, and religious education are seemingly unrelated facts which I have tried to bring into the mutual and, for the quality of education, stimulating relationship, and thus enrich the discourse of (religious) education in our environment. Finally, I will mention two important challenges. As religious pedagogy is a 'borderline' field, I address the first challenge within theological discourse, and the second one within pedagogical discourse.

The first challenge is directed to the communion of the Church which, by letting fairy tales and other figurative stories into its educational content and reviving a sense of telling not only biblical stories but also stories that contribute to the understanding of biblical stories, can once again become, in the words of Johann Baptist Metz, a place of 'remembrance' and thus regain its credible face. ${ }^{87}$ It means the courage to abandon a certain 'colonial' mentality, coupled with an ambition to control, and discover the value of many small stories of specific people. ${ }^{88}$

The second challenge, on the other hand, is aimed at general educators so that they will not be afraid to appreciate Christianity with its rich reservoir of narratives. They can enrich general educational content and help personality development. Even here the ideas are valid of the researcher of John Amos Comenius, Jan Hábl, who says, 'a person exposed to the power of a story is a being who experiences a holistic experience in which he thinks, feels, believes, experiences, identifies himself with someone or something, receives information, evaluates, etc. ${ }^{89}$ At the end of his study, Hábl proposes the rehabilitation of narrative discourse in pedagogy, and introduces the concept of didactic narrativisation. He sees this as a two-level methodological principle which reads: whatever can be communicated narratively, let it be translated into this form. Let all material that is narrativisable be narrativised.

\author{
Contact \\ Dr Tomáš Cyril Havel \\ University of South Bohemia in České Budějovice \\ Faculty of Theology \\ Department of Education \\ Kněžská 8, 37001 České Budějovice \\ thavel@tf.jcu.cz
}

\footnotetext{
86 Tomáš Cyril HAVEL and Eva MUROŇOVÁ (eds.), Odkud mám jméno: Metodika ke katechezím o svatých, Brno: Kartuziánské nakladatelství, 2013; Tomáš Cyril HAVEL and Eva MUROŇOVÁ (eds.), Naplnil se čas, Brno: Kartuziánské nakladatelství, 2012; Eva MUROŇOVÁ, Margot EDEROVÁ and Tomáš Cyril HAVEL, Aby malé bylo velké, Brno: Kartuziánské nakladatelství, 2008.

87 METZ, Glaube...

88 See more in STREIB, Erzählte Zeit..., p. 198.

89 Jan HÁBL, Učit (se) př́iběhem: Komenského Labyrint a didaktické možnosti narativní alegorie, Brno: Host, 2013, p. 55.
} 